\title{
Performance standards and residential energy efficiency in Egypt
}

\author{
K. Tiedemann \\ BC Hydro and Simon Fraser University, Canada
}

\begin{abstract}
The Egypt Organization for Energy Planning (OEP) has put in place energy efficiency labels and standards to increase energy efficiency in the residential sector. In the first phase, energy efficiency standards were put in place for three household appliances - refrigerators, washing machines and air conditioners. In the second phase, energy efficiency labels and standards are being considered for three more end use technologies - electric water heaters, electric lighting and electric motors. The purpose of this paper is to report on an impact evaluation of recent Egyptian minimum energy performance standards for residential appliances.
\end{abstract}

Keywords: energy conservation, program evaluation, energy efficiency, greenhouse gas emissions.

\section{Introduction}

Egypt has considerable endowments of energy resources including natural gas, petroleum and hydro-electric power. As a result of investments in the energy sector and strong and increasing demand, the rate of growth of primary energy production has more than kept pace with the growth of population over the past twenty years. The Government of Egypt has historically kept energy prices at below world levels to foster economic development and to provide economic benefits to residential energy consumers. As result, energy use is at a relatively high level compared to many other countries with similar levels of income or GDP per capita.

With respect to electricity prices, tariffs have been quite low although the Government of Egypt has made efforts to increase electricity prices to reduce the gap between selling prices and long-term supply costs. Various estimates suggest 
that the ratio of average price paid for electricity across all customer groups as a proportion of long term marginal cost is from $80 \%$ to over $100 \%$. Not withstanding the overall price-cost situation, many residential electricity customers are still heavily subsidized.

There are significant opportunities to increase energy efficiency in the residential, commercial and industrial sectors in Egypt. The Government of Egypt has recognized the importance of these opportunities and passed enabling legislation in the form of the National Environmental Law of 1993. Subsequent activities included preparation of a National Climate Change Plan and National Strategy for Improving Energy Efficiency in Egypt. The objectives of these policies include: improving energy efficiency, reducing energy consumption and reducing greenhouse gas emissions.

A number of market barriers have been identified which limit the adoption of energy efficient technologies in Egypt. These include:

- Low residential, commercial and industrial customer awareness and knowledge of the nature and benefits of specific energy efficient techniques and practices;

- Relatively low residential, commercial and industrial customer interest in purchasing and adopting these technologies and practices;

- Reluctance to invest in capital projects even with paybacks as rapid as two or three years;

- $\quad$ Risk aversion towards the adoption of new technologies; and

- Inadequate market infrastructure in terms of the availability of efficient equipment and appropriate skills and knowledge for the support of installation and maintenance and use of high efficiency equipment.

To help overcome these barriers, the Organization for Energy Planning (OEP) has been established with a mandate to put in place energy efficiency labels and standards. In the first phase, energy efficiency standards were put in place for three household appliances - refrigerators, washing machines and air conditioners. In the second phase, energy efficiency labels and standards are being considered for three more end use technologies - electric water heaters, electric lighting and electric motors.

The purpose of this paper is to report on an impact evaluation of recent Egyptian minimum energy performance standards (MEPS) for residential appliances. Engineering analysis was used to estimate the impact of the program on incremental sales of efficient appliances, energy savings, and reductions in carbon dioxide emissions.

\section{Overview of residential electricity use}

Table 1 summarizes the key results of several surveys of residential electricity use that have been undertaken in Egypt over the past ten years. Average annual 
consumption per household varies from about $1,800 \mathrm{kWh}$ in Alexandria Governorate in 1994 to about 3,200 kWh in Luxor Governorate in 2002.

Table 1: Average residential energy consumption.

\begin{tabular}{|l|l|l|l|}
\hline Governorate & Year of survey & $\begin{array}{l}\text { Monthly } \\
\text { consumption } \\
(\mathrm{kWh})\end{array}$ & $\begin{array}{l}\text { Annual } \\
\text { consumption } \\
(\mathrm{kWh})\end{array}$ \\
\hline Alexandria & 1994 & 149 & 1788 \\
\hline Suez & 1995 & 208 & 2496 \\
\hline Port Said & 1996 & 214 & 2568 \\
\hline Cairo & 2000 & 239 & 2868 \\
\hline Luxor & 2002 & 267 & 3204 \\
\hline Assuit & 2002 & 225 & 2700 \\
\hline Average & & 217 & 2604 \\
\hline
\end{tabular}

Source: Egypt Organization for Energy Planning.

Table 2 provides information on residential electricity consumption by end use, and this information may be viewed as broadly representative of the residential sector in Egypt. Important end uses by consumption level are lighting, refrigerators, water heating, television, and air conditioners.

Table 2: $\quad$ Residential end use consumption, Cairo, 2000.

\begin{tabular}{|l|l|l|l|l|}
\hline Appliance & $\begin{array}{l}\text { Unit energy } \\
\text { consumption } \\
(\mathrm{kWh})\end{array}$ & $\begin{array}{l}\text { Saturation } \\
\text { rate } \\
(\%)\end{array}$ & $\begin{array}{l}\text { Average } \\
\text { consumption } \\
(\mathrm{kWh})\end{array}$ & $\begin{array}{l}\text { Consumption } \\
\text { share } \\
(\%)\end{array}$ \\
\hline Television & 303 & 96 & 290 & 10.1 \\
\hline Radio/cassette & 172 & 92 & 158 & 5.5 \\
\hline Fan & 137 & 90 & 123 & 4.3 \\
\hline Refrigerator & 555 & 93 & 516 & 18.0 \\
\hline Washer & 157 & 97 & 152 & 5.3 \\
\hline Water heater & 1055 & 31 & 327 & 11.4 \\
\hline Air conditioner & 1980 & 12 & 198 & 6.9 \\
\hline Iron & 88 & 91 & 80 & 2.8 \\
\hline Lighting & 872 & 100 & 872 & 30.4 \\
\hline Other & - & - & 155 & 5.4 \\
\hline Total & - & - & 2868 & 100.0 \\
\hline
\end{tabular}

Source: Egypt Organization for Energy Planning.

\section{Refrigerators}

The basis for regulation of labeling and standards for refrigerators is Egypt (2003) Ministerial Decree 180/2003, Egyptian Energy Standards for Refrigerators, Refrigerator-Freezers and Freezers. The label allows the consumer to compare energy efficiency among refrigerators or freezers with the same 
capacity. The labels include information on the manufacturer's name or trade mark; adjusted volume in liters; maximum energy consumption for similar products; minimum energy consumption for similar products; energy consumption of the specific unit; and efficiency grade on a five-point scale.

Several technologies can be used to improve the energy performance of refrigerators and freezers to meet the minimum energy performance standards. These include more efficient motors, improved compressors, more accurate temperature controls, higher quality insulation and improved gaskets and seals.

A key concept used in the minimum energy performance standards is that of adjusted volume. The adjusted volume for refrigerators is given by equation (1), and the adjusted volume for freezers is given by equation (3). Equation (2) provides the adjustment factor.

$$
\begin{gathered}
A V_{R}=V_{R}+A_{F} * V_{F} \\
A_{F}=\left(T_{A}-T_{F}\right) /\left(T_{A}-T_{R}\right) \\
A V_{F}=A_{F} * V_{F}
\end{gathered}
$$

where,
$A V_{R}=$ adjusted volume of the refrigerator in liters
$A_{F}=$ adjustment factor
$V_{R}=$ net volume of the fresh food compartment
$\mathrm{V}_{\mathrm{F}}=$ net volume of the freezer
$\mathrm{T}_{\mathrm{A}}=$ ambient temperature in the test area of 32 degrees Celsius
$\mathrm{T}_{\mathrm{F}}=$ standard temperature of the freezer, typically -6 degrees.

Table 3: $\quad$ Refrigerator minimum energy performance standards.

\begin{tabular}{|l|l|l|}
\hline Product Type & \multicolumn{2}{|l|}{ Maximum consumption in kWh per year } \\
\hline $\begin{array}{l}\text { 1-door refrigerator, manual } \\
\text { defrost }\end{array}$ & $0.48 \mathrm{AV}+784$ & $0.48 \mathrm{AV}+627$ \\
\hline $\begin{array}{l}\text { 2-door refrigerator, partial } \\
\text { automatic defrost }\end{array}$ & $0.37 \mathrm{AV}+721$ & $0.37 \mathrm{AV}+577$ \\
\hline $\begin{array}{l}\text { 2-door refrigerator, } \\
\text { automatic defrost }\end{array}$ & $0.57 \mathrm{AV}+1130$ & $0.57 \mathrm{AV}+904$ \\
\hline $\begin{array}{l}\text { Upright freezer, manual } \\
\text { defrost }\end{array}$ & $0.36 \mathrm{AV}+330$ & $0.36 \mathrm{AV}+264$ \\
\hline $\begin{array}{l}\text { Upright freezer, automatic } \\
\text { defrost }\end{array}$ & $0.53 \mathrm{AV}+469$ & $0.53 \mathrm{AV}+375$ \\
\hline Chest freezer refrigerator, less & $0.39 \mathrm{AV}+979$ & $0.39 \mathrm{AV}+784$ \\
\hline $\begin{array}{l}\text { Compact } \\
\text { than 14 liters }\end{array}$ & $0.48 \mathrm{AV}+408$ & $0.48 \mathrm{AV}+326$ \\
\hline Refrigerator without freezer & $0.48 \mathrm{AV}+300$ & $0.48 \mathrm{AV}+270$ \\
\hline
\end{tabular}

Source: Egypt Organization for Energy Planning.

Table 3 summarizes the maximum limit of energy consumption for various models of refrigerators and freezers. Initial performance requirements were 
established for 2003 and these were made more stringent for 2005 . Table 4 estimates customer energy savings due to minimum energy performance standards for refrigerators. The above MEPS share is the estimated share of product not meeting the minimum energy performance standard before program launch (that is, consumption is above MEPS). Annual added compliant units are the product of sales in millions of units (mn), the above MEPS share and the assumed compliance rate. Annual customer savings is the product of added sales and unit savings and this is cumulated to estimate the level of cumulative annual savings over time due to the gradual switch over in the capital stock to the efficient product.

Table 5 estimates generation and carbon dioxide savings. Annual customer savings times system loss factor (one plus the eight percent of electricity generated lost in transmission) gives cumulative annual system savings at the generation level. Cumulative annual system savings times the emissions factor provides the annual reduction in carbon dioxide.

Table 4: $\quad$ Customer refrigerator savings analysis.

\begin{tabular}{|l|l|l|l|l|l|l|}
\hline Year & $\begin{array}{l}\text { Sales } \\
(\mathrm{mn})\end{array}$ & $\begin{array}{l}\text { Above } \\
\text { MEPS } \\
\text { share }\end{array}$ & $\begin{array}{l}\text { Compliance } \\
\text { rate }\end{array}$ & $\begin{array}{l}\text { Annual } \\
\text { added } \\
\text { compliant } \\
\text { units } \\
(\mathrm{mn})\end{array}$ & $\begin{array}{l}\text { Unit } \\
\text { saving } \\
\text { (kWh per } \\
\text { year) }\end{array}$ & $\begin{array}{l}\text { Annual } \\
\text { customer } \\
\text { saving } \\
\text { (GWh) }\end{array}$ \\
\hline 2003 & 1.068 & 0.60 & 0.75 & 0.481 & 64 & 30.8 \\
\hline 2004 & 1.098 & 0.60 & 0.75 & 0.494 & 64 & 31.6 \\
\hline 2005 & 1.135 & 0.80 & 0.75 & 0.681 & 120 & 81.7 \\
\hline
\end{tabular}

Table 5: $\quad$ System refrigerator savings analysis.

\begin{tabular}{|l|l|l|l|l|l|l|}
\hline & $\begin{array}{l}\text { Annual } \\
\text { customer } \\
\text { saving } \\
(\mathrm{GWh})\end{array}$ & $\begin{array}{l}\text { Cumulative } \\
\text { annual } \\
\text { customer } \\
\text { saving } \\
(\mathrm{GWh})\end{array}$ & Loss & $\begin{array}{l}\text { Cumulative } \\
\text { annual } \\
\text { system } \\
\text { saving } \\
(\mathrm{GWh})\end{array}$ & $\begin{array}{l}\text { Emissions } \\
\text { factor } \\
(\mathrm{kt} \text { per } \\
\text { GWh) }\end{array}$ & $\begin{array}{l}\text { Annual } \\
\mathrm{CO}_{2} \\
\text { reduction } \\
\text { (ktonne) }\end{array}$ \\
\hline 2003 & 30.8 & 30.8 & 1.08 & 33.3 & 0.506 & 16.8 \\
\hline 2004 & 31.6 & 62.4 & 1.08 & 67.4 & 0.506 & 34.1 \\
\hline 2005 & 81.7 & 144.1 & 1.08 & 155.6 & 0.506 & 78.7 \\
\hline Total & & & & & & 129.6 \\
\hline
\end{tabular}

\section{Clothes washers}

The basis for regulation of labeling and standards for washing machines is Egypt (2003) Ministerial Decree 4100/2003, Measurement and Calculation Methods of Household Clothes Washing Machines. The label includes the following information: manufacturer name or trademark; model; capacity in kilograms; maximum energy consumption for this type of product; minimum energy consumption for this type of product; energy consumption of the unit; efficiency grade. The minimum energy performance standard is $0.26 \mathrm{kWh}$ per kilogram per load. The energy efficiency of clothes washers can be improved by using more 
efficient motors, better sizing of the motor to the load, and more efficient transmissions.

Table 6 estimates customer energy savings for clothes washers due to minimum energy performance standards. Annual customer savings is the product of added sales and unit savings and this is cumulated to estimate the level of cumulative annual savings over time due to the gradual switch over in the capital stock to the efficient product. Cumulative annual savings times the system loss factor gives cumulative annual system savings (these are savings at the generation level). Finally cumulative annual system savings times the emissions factor provides the annual reduction in carbon dioxide.

Table 6: Customer clothes washer savings analysis.

\begin{tabular}{|l|l|l|l|l|l|l|}
\hline Year & $\begin{array}{l}\text { Sales } \\
(\mathrm{mn})\end{array}$ & $\begin{array}{l}\text { Above } \\
\text { MEPS } \\
\text { share }\end{array}$ & $\begin{array}{l}\text { Compliance } \\
\text { rate }\end{array}$ & $\begin{array}{l}\text { Annual } \\
\text { added } \\
\text { compliant } \\
(\mathrm{mn})\end{array}$ & $\begin{array}{l}\text { Annual } \\
\text { Unit } \\
\text { saving } \\
(\mathrm{kWh})\end{array}$ & $\begin{array}{l}\text { Annual } \\
\text { customer } \\
\text { saving } \\
(\mathrm{GWh})\end{array}$ \\
\hline 2003 & 0.368 & 0.70 & 0.75 & 0.193 & 50 & 9.7 \\
\hline 2004 & 0.378 & 0.70 & 0.75 & 0.198 & 50 & 9.9 \\
\hline 2005 & 0.391 & 0.70 & 0.75 & 0.205 & 50 & 10.3 \\
\hline
\end{tabular}

As shown in table 7, cumulative annual savings times the system loss factor gives cumulative annual system savings or savings at the generation level. Cumulative annual system savings times the emissions factor provides the annual reduction in carbon dioxide.

Table 7: $\quad$ System clothes washer savings analysis.

\begin{tabular}{|l|l|l|l|l|l|l|}
\hline Year & $\begin{array}{l}\text { Annual } \\
\text { customer } \\
\text { saving } \\
(\mathrm{GWh})\end{array}$ & $\begin{array}{l}\text { Cumulative } \\
\text { annual } \\
\text { Customer } \\
\text { saving } \\
(\mathrm{GWh})\end{array}$ & Loss & $\begin{array}{l}\text { Cumulative } \\
\text { annual } \\
\text { system } \\
\text { saving } \\
(\mathrm{GWh})\end{array}$ & $\begin{array}{l}\text { Emissions } \\
\text { factor } \\
\text { (kt per } \\
\text { GWh) }\end{array}$ & $\begin{array}{l}\text { Annual } \\
\mathrm{CO}_{2} \\
\text { reduction } \\
\text { (ktonne) }\end{array}$ \\
\hline 2003 & 9.7 & 9.7 & 1.08 & 10.5 & 0.506 & 5.3 \\
\hline 2004 & 9.9 & 19.6 & 1.08 & 21.2 & 0.506 & 10.7 \\
\hline 2005 & 10.3 & 29.9 & 1.08 & 32.3 & 0.506 & 16.3 \\
\hline Total & & & & & & 32.3 \\
\hline
\end{tabular}

\section{Air conditioners}

The basis for regulation of labeling and standards for air conditioners is Egypt (2003) Ministerial Decree 4100/2003, Measurement and Calculation Methods of Household Clothes Washing Machines. The label includes the following information: manufacturer name or trademark; model; capacity in kilograms; maximum energy consumption for this type of product; minimum energy consumption for this type of product; energy consumption of the unit; efficiency grade. The minimum energy efficiency ratio (EER) for window type air conditioners is 8.5 and 9.0 for split type air conditioners. The energy efficiency 
of air conditioners can be increased by using more efficient motors, using better compressors, and improving thermostats and air conditioner controls.

Table 8 estimates customer energy savings for air conditioners due to minimum energy performance standards. Annual customer savings is the product of added sales and unit savings and this is cumulated to estimate the level of cumulative annual savings over time due to the gradual switch over in the capital stock to the efficient product.

Table 8: $\quad$ Customer air conditioner savings analysis.

\begin{tabular}{|l|l|l|l|l|l|l|}
\hline Year & $\begin{array}{l}\text { Sales } \\
(\mathrm{mn})\end{array}$ & $\begin{array}{l}\text { Above } \\
\text { MEPS } \\
\text { Share }\end{array}$ & $\begin{array}{l}\text { Compliance } \\
\text { rate }\end{array}$ & $\begin{array}{l}\text { Annual } \\
\text { added } \\
\text { compliant } \\
\text { units } \\
(\mathrm{mn})\end{array}$ & $\begin{array}{l}\text { Unit } \\
\text { saving } \\
(\mathrm{kWh} \text { per } \\
\text { year })\end{array}$ & $\begin{array}{l}\text { Annual } \\
\text { customer } \\
\text { saving } \\
(\mathrm{GWh})\end{array}$ \\
\hline 2003 & 0.577 & 0.60 & 0.75 & 0.260 & 165 & 42.8 \\
\hline 2004 & 0.592 & 0.60 & 0.75 & 0.266 & 165 & 44.0 \\
\hline 2005 & 0.610 & 0.60 & 0.75 & 0.275 & 165 & 45.3 \\
\hline
\end{tabular}

As shown in table 9, cumulative annual savings times the system loss factor gives cumulative annual system savings or savings at the generation level. Cumulative annual system savings times the emissions factor provides the annual reduction in carbon dioxide.

Table 9: $\quad$ System air conditioner savings analysis.

\begin{tabular}{|l|l|l|l|l|l|l|}
\hline Year & $\begin{array}{l}\text { Annual } \\
\text { customer } \\
\text { saving } \\
(\mathrm{GWh})\end{array}$ & $\begin{array}{l}\text { Cumulative } \\
\text { annual } \\
\text { Customer } \\
\text { saving } \\
(\mathrm{GWh})\end{array}$ & Loss & $\begin{array}{l}\text { Cumulative } \\
\text { annual } \\
\text { system } \\
\text { saving } \\
(\mathrm{GWh})\end{array}$ & $\begin{array}{l}\text { Emissions } \\
\text { factor } \\
(\mathrm{kt} \text { pt } \\
\mathrm{GWh})\end{array}$ & $\begin{array}{l}\text { Annual } \\
\mathrm{CO}_{2} \\
\text { reduction } \\
\text { (ktonne) }\end{array}$ \\
\hline 2003 & 42.8 & 42.8 & 1.08 & 46.2 & 0.506 & 23.4 \\
\hline 2004 & 44.0 & 86.8 & 1.08 & 93.7 & 0.506 & 47.4 \\
\hline 2005 & 45.3 & 132.1 & 1.08 & 142.7 & 0.506 & 72.2 \\
\hline Total & & & & & & 143.0 \\
\hline
\end{tabular}

\section{Conclusions}

In this study, we have analysed the impact of the Government of Egypt's minimum energy performance standards for residential appliances. Key findings are as follows.

(1) Residential Energy Use. Average residential electricity use in Egypt is about 2,600 kWh per household per year. Unit energy consumption per year for major uses are $1980 \mathrm{kWh}$ for air conditioning, $1055 \mathrm{kWh}$ for water heating, $872 \mathrm{kWh}$ for lighting, $555 \mathrm{kWh}$ for refrigerators, $303 \mathrm{kWh}$ for televisions, 172 $\mathrm{kWh}$ for radio/cassettes, $157 \mathrm{kWh}$ for washers, $137 \mathrm{kWh}$ for fans and $88 \mathrm{kWh}$ for irons. 
(2) Refrigerators. Refrigerator sales are about 1.1 million units per year, with about 60 percent of units in the base year 2001 not meeting the 2003 performance standards. Electricity saving for refrigerators was about $30.8 \mathrm{GWh}$ in 2003, 62.4 GWh in 2004 and 144.1 GWh in 2005. Carbon dioxide savings were about 16.8 ktonnes in 3003, 34.1 ktonnes in 2004 and 78.7 ktonnes in 2005.

(3) Clothes Washers. Clothes washer sales are about 0.4 million units per year, with about 70 percent of units in the base year 2001 not meeting the 2003 performance standards. Electricity saving for clothes washers was about 9.7 GWh in 2003, 9.9 GWh in 2004 and $10.3 \mathrm{GWh}$ in 2005. Carbon dioxide savings were about 5.3 ktonnes in 2003, 10.7 ktonnes in 2004 and 16.3 ktonnes in 2005.

(4) Air Conditioners. Air conditioners sales are about 0.6 million units per year, with about 60 percent of units in the base year 2001 not meeting the 2003 performance standards. Electricity saving for air conditioners was about 42.8 GWh in 2003, 44.0 GWh in 2004 and 45.3GWh in 2005. Carbon dioxide savings were 23.4 ktonnes in 2003, 47.4 ktonnes in 2004 and 72.2 ktonnes in 2005 .

\section{References}

[1] Economist Intelligence Unit Egypt Survey, 2005.

[2] S J. Huang, J. Deringer, M. Krarti and J. Masud, Development of Residential and Commercial Building Energy Standards for Egypt, Proceedings of the Energy Conservation in Buildings Workshop, Kuwait, 2003.

[3] United Nations Development Program. United Nations Program of Technical Cooperation. Energy Efficiency Improvements. Project No. EGY97G31, 2005.

[4] World Energy Council, Energy Information: Egypt. Extract from the Survey of Energy, 2005.

[5] Egypt Organization for Energy Planning, Energy Efficiency Improvements and Greenhouse Gas Reduction, 1st Interim Report, Residential Customers Survey, 1998.

[6] Egypt Organization for Energy Planning, Energy Efficiency Improvements and Greenhouse Gas Reduction. 6th Interim Report. Measuring and Testing Method for Refrigerators and Refrigerator-Freezers, 2004.

[7] Egypt Organization for Energy Planning, Energy Efficiency Improvements and Greenhouse Gas Reduction. 7th Interim Report. Measuring and Testing Method for Air Conditioners, 2004.

[8] Egypt Organization for Energy Planning, Energy Efficiency Improvements and Greenhouse Gas Reduction. 8th Interim Report. Measuring and Testing Method for Clothes Washers, 2004. 